\title{
ALBERTAN GAS STORAGE RESERVOIRS: A NEW DIRECTION FOR ROYALTY ADMINISTRATION
}

\author{
COLIN Q. WINTER*
}

The Alberta Government and Alberta Energy Company Lid. have entered into an Agreement for that company to own and operate, for itself and other Storers, an operationally fully diversified, gas storage reservoir at Suffield, Alberta. This Agreement circumvents the existing Alberta regulations and offers us an insight into current Alberta Government policy for Alberta Crown royalty obligations created by upstream storage in Alberta.

\section{TABLE OF CONTENTS}

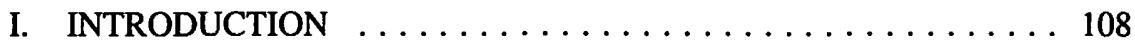

II. THE REGULATORY REGIME FOR STORAGE IN ALBERTA . . . . . . . . . . . . . . . . 109

A. SECTION 17 OF REGULATION $246 / 90 \ldots \ldots \ldots \ldots \ldots 109$

B. SECTION 8 OF SCHEDULE 1

OF REGULATION $246 / 90 \ldots \ldots \ldots \ldots \ldots \ldots \ldots \ldots$

III. OPERATIONAL REQUIREMENTS

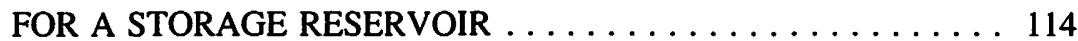

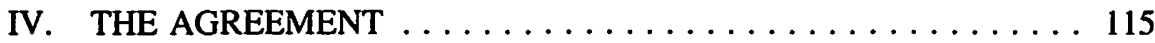

A. AUTHORITY FOR AGREEMENT $\ldots \ldots \ldots \ldots \ldots \ldots 116$

B. APPLICATION OF SECTION 8

OF SCHEDULE $1 \ldots \ldots \ldots \ldots \ldots \ldots \ldots \ldots \ldots \ldots$

C. APPLICATION OF SECTION $17 \ldots \ldots \ldots \ldots \ldots \ldots \ldots 118$

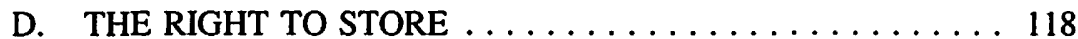

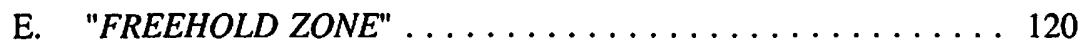

F. OBLIGATION TO PAY THE

ALBERTA ROYALTY SHARE . . . . . . . . . . . . . . 120

G. FUEL GAS WILL BE SUBJECT

TO ALBERTA ROYALTY . . . . . . . . . . . . . . 120

H. NO DEDUCTIONS EQUIVALENT TO GCA $\ldots \ldots \ldots \ldots 121$

I. LEASES AND AGREEMENT

ARE INDEPENDENT . . . . . . . . . . . . . . . 122

J. SUBSCRIPTION AGREEMENTS $\ldots \ldots \ldots \ldots \ldots \ldots \ldots 122$

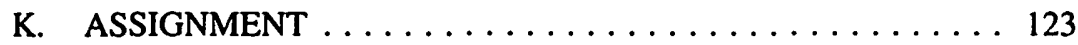

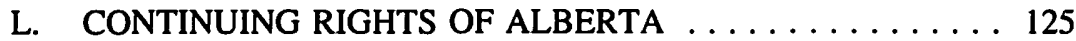

M. FEES TO ALBERTA FOR PROVIDING

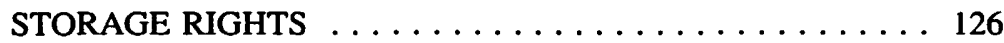

N. NATIVE GAS AND CUSHION GAS $\ldots \ldots \ldots \ldots \ldots \ldots 126$

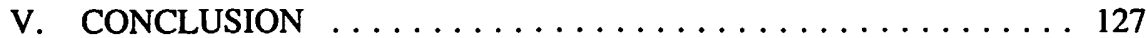

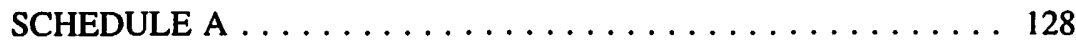

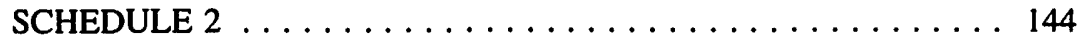

SCHEDULE $3 \ldots \ldots \ldots \ldots \ldots \ldots \ldots \ldots \ldots \ldots \ldots \ldots$

Staff Counsel, Alberta Energy Company Lıd., Calgary, Alberta. 


\section{INTRODUCTION}

After four years of negotiations between Alberta Energy Company Ltd. ("AEC") and the Alberta Department of Energy for the Government of Alberta ("Alberta"), AEC has secured a natural gas storage agreement which cuts across the existing Alberta regulations. The agreement is referred to as the "Suffield Upper Mannville I Crown Storage Agreement" ("Agreement"). ${ }^{\prime}$ As the name suggests, the reservoir is located at the Suffield Military Range in south east Alberta in the Upper Mannville Formation I pool of the Suffield field. ${ }^{2}$

These three features of the Agreement are particularly notable.

\section{Simple Administration}

There is a simple administrative system for both Alberta and users of storage for reporting injection and removal volumes and for calculating and paying royalty on the injected volumes.

\section{Incentive to Use Storage}

The requirement to pay Alberta's royalty share upon injection at "CAP," a storer's Corporate Average Price for that injection month, provides a material incentive for Alberta producers to use storage for other producers to consider additional facility developments within Alberta.

\section{Accessibility to a Broad Range of Producers}

The ability provided to storers to assign their storage rights will provide access to storage to both those producers able to secure firm storage rights agreements with AEC and to other producers looking for firm or interruptible storage rights. The latter will be able to contract directly with AEC, or indirectly by assignment through those producers who have arranged for firm storage accessibility.

Suffield Upper Mannville I Crown Storage Agreement between Her Majesty the Queen in the Right of Alberta and Alberta Energy Company Lid., approved for Her Majesty by Order in Council 544/92 issued September 23, 1992, by the Lieutenant Governor in Council for the Province of Alberta.

When defined terms in the Agreement are first used in this paper, they will be referred to in quotation marks and with initial capitals.

2 $\quad$ R.K. Eresman, R.A. Grant and N. Mungan. "Suffield Upper Mannville I Gas Storage Project" (1990) Society of Petroleum Engineers, Preprint Paper No. 20767 65th Annual Technical Conference and Exhibition, New Orleans, LA, September 23-26, 1990, 493.

Alberta recognizes the Reservoir to have a size of 7,232 hectares of Alberta Crown lease land and 400 hectares of AEC freehold mineral land rights.

The location is a narrow north/south trending Lower Cretaceous sand body over Townships 16, 17 and 18, Range $9 \mathrm{~W} 4 \mathrm{M}$; that is, along the western margin of the Suffield Military Range, south east Alberta. After an expansion to the facilities located at the AECO C Station which AEC plans to make in 1993, the nominal daily withdrawal rate will be 500 million standard cubic feet per day. The nominal working gas volume is 18 billion cubic feet, and the ultimate working gas volume is 28 billion cubic feet. 


\section{THE REGULATORY REGIME FOR STORAGE IN ALBERTA}

Effective January 1, 1988, Alberta proclaimed into force Natural Gas Royalty Amendment Regulation (Alta. Reg. 513/87) to the Mines and Minerals Act R.S.A. 1980 c. M-15, as amended ("Mines and Minerals Act"). This Regulation introduced two important provisions relating to the injection of gas.

These provisions were:

1. Injection for Storage Only: Alberta introduced section 7 to Schedule 1 of The Natural Gas Royalty Regulations (Alta. Reg. 16/74);

2. Injection for Purposes other than Storage: Alberta repealed the existing section 4 and introduced new section 4 to The Natural Gas Royalty Regulations (Alta. Reg. 16/74).

In 1990, The Natural Gas Royalty Regulations (Alta. Reg. 16/74, as amended) were replaced by The Natural Gas Royalty Regulation (Alta Reg. 246/90) ("Regulation 246/90"). Section 4 became section 17; section 7 of Schedule I became section 8 of Schedule 1. Each restatement was made without amendment.

\section{A. SECTION 17 OF REGULATION 246/90}

\section{7(1) Subject to subsection (2), if}

(a) natural gas that is subject to the payment of royalty to the Crown is injected into a pool other than the pool from which it was recovered and had not been sold or otherwise disposed of to another person prior to being injected, or

(b) a gas product that is subject to the payment of royalty to the Crown is injected into a pool and the natural gas from which the gas product was obtained was not originally recovered from that pool and had not been sold or otherwise disposed of to another person prior to being injected, unless the Minister otherwise directs, the Crown's royalty share of the natural gas or gas products shall be injected into the same pool for the same purpose and, on being injected royalty is payable to the Crown on that natural gas or gas product unless the Minister otherwise directs.

(2) The Minister shall not make a direction under subsection (1) that no royalty is payable on any natural gas or gas product if he is satisfied that the result of the direction would be that the Crown would ultimately receive less royalty than if the direction were not made.

(3) No royalty is payable to the Crown on natural gas or a gas product if

Alta. Reg. 246/90 filed August 9, 1990; section 31. When defined terms in the Mines and Minerals Act or this Regulation are used in this paper, they will be referred to in quotation marks without initial capitals. 
(a) the natural gas is injected into the same pool from which it was recovered, or

(b) the gas product is injected into a pool and the natural gas from which the gas product was obtained was originally recovered from that pool.

and the natural gas or gas product had not been sold or otherwise disposed of to another person prior to being injected.

\section{Interpretation \#1 of Section $17^{4}$}

While the section does not make any mention of a purpose for which a lessee may inject gas, Alberta interprets this section to apply only to the injection gas for purposes other than for storage and interprets this section to be mutually exclusive of the application of section 8 of Schedule $1 .^{5}$

When Alberta introduced the predecessor sections to section 17 and section 8 of Schedule 1, effective January 1, 1988, Alberta focused its attention on the need to include provisions governing injection for both storage and other purposes, such as enhanced recovery. Where gas was injected for those other purposes, Alberta preferred to effect a valuation for royalty payment purposes at the point of injection. Alberta did not see a need to restrict the application of section 17 to injection for any particular purpose, because the provisions of the new scheme created by section 8 of Schedule 1 clearly and specifically limited the application of that section to injection for the purpose of storage.

\section{Interpretation \#2 of Section 17}

When an owner of gas, which includes a Crown royalty share, injects that gas for a purpose other than storage into a pool other than that from which that owner obtains that gas, Alberta interprets the owner to be required to pay for that royalty share at an amount the Minister may determine as the "fair value" of natural gas or gas product.

Alberta therefore interprets that $80 \%$ AMP pricing ("Alberta average market price") to be inapplicable to the valuation of the Alberta royalty share of natural gas or gas products which a producer injects for a purpose other than for storage under section 17.

Alberta reaches this interpretation by applying Regulation $246 / 90$ as follows.

1. "Volumes sold" includes volumes of gas or gas products injected into a pool for a purpose other than for storage, without having been sold or otherwise disposed of to another person. ${ }^{6}$

Alta. Reg. 246/90 Schedule 1. "Natural Gas and Residue Gas." Whenever this paper refers to "section 17 or to "section 8 of Schedule 1", that reference shall be to footnotes 3 and 4 respectively.

s Alberta presented these interpretations to the writer during the negotiation process for the Agreement.

$6 \quad$ Supra note 3 section 1(1)(qq). 
2. "Volumes sold" for a production month which include an Alberta royalty share, are subject to the payment of royalty at the greater of a "selling price" and $80 \%$ of AMP, where the selling price is either a sale price adjusted for gathering, transportation and processing expenses or, if the Minister determines, the fair value of natural gas. ${ }^{7}$

3. Where a producer injects natural gas or gas products into a pool for a purpose other than for storage, the Minister may determine the fair value of that natural gas to be a reasonable price of that natural gas, having regard to market conditions that would be expected to affect that price and the public interest of Alberta. ${ }^{8}$

Rather than permitting the producer to report a deemed sale at $80 \%$ of AMP for the natural gas or gas product which that producer injects for a purpose other than for storage, the Minister chooses to rely upon this authority to require that producer to report the deemed sale and to pay for the Alberta royalty share, at a "fair value."

Alberta perceives the Minister's role in determining the "fair value" of natural gas or a gas product value as one he will exercise reactively. That is, the Minister will expect the injecting producer to calculate and pay the Alberta royalty share at a price which the producer will be required to determine as a "fair value", with the Minister reserving the right to subsequently redetermine and look for adjustment in the royalty paid.

Alberta's interpretation that the producer must pay a "fair value" for the Alberta royalty share of natural gas or gas products which that producer injects for a purpose other than for storage is consistent with Alberta's specific evaluation requirement for gas injected for the purpose of storage and remaining in storage after 12 months under section 8(2)(a) of Schedule 1 .

\section{B. SECTION 8 OF SCHEDULE 1 OF REGULATION 246/90}

8 (1) Subject to subsection (2), if

(a) any natural gas or residue gas obtained or delivered in January, 1988 or any subsequent month is injected into a pool for the purpose of storage without having been sold or otherwise disposed of to another person,

(b) the Crown's royalty share of the natural gas or residue gas remains in storage at the end of the 12 th month following the month in which it was so injected,

for the purposes of this Regulation, the Crown's royalty share of the natural gas or residue gas shall be deemed to be volumes sold for that 12 th month. 
(2) Notwithstanding section 7 of this schedule or any provision of section 1 of this Regulation,

(a) there shall be paid to the Crown in accordance with this Regulation, in respect of the Crown's royalty share of natural gas or residue gas referred to in subsection (1), an amount equal to the fair value of that royalty share as determined by the Minister, and

(b) the Minister may, in determining the fair value of the Crown's royalty share under clause (a), have regard to the market conditions during the 12-month period referred to in subsection (1) and the public interest of Alberta.

(3) If

(a) any natural gas or residue gas had been injected into a pool in Alberta in a month preceding January, 1988 for the purpose of storage without having been sold or otherwise disposed of to another person, and

(b) the natural gas or residue gas is recovered from storage in January, 1988 or any subsequent month,

the natural gas or reside gas shall be deemed to initially be obtained or delivered for the purposes of this Regulation the month during which it was recovered from storage.

These are the salient features of this section.

\section{Royalty Deferral}

This section created a new regime for injection of gas for storage.

Under section 8 of Schedule 1, storers are afforded the opportunity to store their gas, which contains an Alberta royalty share, for up to twelve months without being required to pay Alberta for that share. If the storers remove their gas within twelve months of injection, they will pay royalty based on the actual sale price obtained after removal of that gas from storage. The royalty payment obligation is deferred from the date of injection and Alberta will be able to share in the optimization of the sales price which the storers will be striving to realize.

Alberta introduced this section using these generalized assumptions:

(a) that the relief of the obligation to pay for Alberta's royalty share at the time of injection would be to the advantage of the storer, thereby removing the obligation to pay royalty under section 17 ;

(b) that storage cycles of injection and removal would be a relatively simple and would be on a "summer season in" and "winter season out" basis; and

(c) that the obligation to pay the Alberta royalty share of twelve month stored gas would be used little, if at all, because the obligation itself and the simple 
seasonality of injection and removal cycles, would ensure that substantially all stored gas would be removed within twelve months of being injected.

\section{2. "First In First Out"}

Section 17 is based on deeming removed gas to be the oldest gas remaining in storage for that storer. This is a "First In First Out" or "FIFO" regime. Actual gas streaming of injection gas would have to be mirrored by deemed gas streaming at removal.

\section{Complex Reporting and Administration}

If the oldest gas in storage has been in storage for twelve months and that gas contains an unpaid Alberta royalty share, the storer will be required to pay for that royalty share at a price, and in the same manner of Ministerial review and adjustment, as provided for the deemed accrual of royalty obligation under sections 17, 1(3)(b)(iv) and 1(4) of Regulation 246/90: that is, the storer will be required to pay at a "fair value" for that gas and not at $80 \%$ of AMP.

FIFO will necessitate detailed reporting requirements. For each storer using the pool, these monthly reporting obligations will need to be made:

(a) the volumes/heat value of gas injected;

(b) the Alberta royalty share of those injected volumes;

(c) the volumes/heat value of gas removed;

(d) the Alberta royalty share of those removed volumes;

(e) the injection month, in which both the removed gas and gas for which the storer pays the Alberta royalty share under the twelve month deemed sale provision, were originally injected;

(f) the volume/heat value of gas remaining in storage for twelve months; and

(g) the Alberta royalty share of that twelve month gas.

\section{Administration Procedures}

Each storer in a pool will be subject to creating a computer program to monitor all the gas storage, gas removal, deemed sales values and sales prices necessary to be able to satisfy what would have to be Alberta's detailed and extensive reporting requirements. While this burden will initially fall upon the storers to discharge, the reporting system could not fail to be complex and would require substantial attention by the staff of Alberta. Administrative complexity is not a goal of industry or of Alberta. 


\section{Intra Pool Sales}

Because FIFO will apply, if a storer wishes to sell stored gas to another storer in that storage pool, that sold gas will have to be the oldest gas of the selling storer: it will have to be deemed to have been removed from storage and the royalty payment provisions will have to be applied to that "removed and sold" gas. For the buying storer, that storer will be deemed to have stored that bought gas at the time of the purchase. That bought gas, now royalty paid, will be the last gas of that buying storer's inventory in storage, which that storer will be allowed to remove from storage. Both storers will be required to make a detailed reporting of the terms of sale in their monthly reporting to Alberta.

\section{Simple Storage Facility}

Section 8 of Schedule 1 is best suited to a simple storage pool operation. Such simplicity would be expressed in:

(a) the number of storers (for example, only the owner of that storage pool);

(b) the classification of stored gas (perhaps all royalty paid/purchased gas or gas from the same source or class); and

(c) the method of injection and removal (all or predominantly all injection to be conducted over a single period within a year and removal over the balance of that year, analogous to a downstream storage facility outside Alberta).

\section{Conclusion}

Section 8 of Schedule 1 creates material difficulties for Alberta, the owner of a storage pool and all users of that pool, if that storage pool is designed to have diversified operations, such as those already experienced in the operation of AEC's Suffield Upper Mannville I Storage Pool.

\section{OPERATIONAL REQUIREMENTS FOR A STORAGE RESERVOIR}

For a storage pool to be fully versatile, the following operational facilities need to be available.

\section{Short Injection and Removal Cycles}

For producers to make full use of their storage opportunities, they need to be able to inject and remove gas in cycles which may be measured in days or even hours. Unlike a downstream facility, an upstream facility services the needs of the producers and not the eventual consumers. Gas being injected into or removed from storage is controlled by the supply side of the supply and demand equation.

Producers with available supplies of gas in upstream storage may choose to use that security of supply to secure long term contracts, in the knowledge that any production 
shortfalls may be satisfied by the supplies in storage. Alternatively, the producers may choose to enter short term or peak demand contracts using those supplies.

\section{Multiple Storers}

Providing storage service (a bailment) is a business unto itself. A storage pool owner may choose to enter into both firm and interruptible storage arrangements with producers. To maximize use of that pool, that pool needs to be available to as many producers as may be necessary to fully utilize all storage capacity at any time.

\section{No Streaming of Gas}

The storers need to be free of any system which would require them to identify individual batches of injection or removal volumes, such as would be required in the use of a $F I F O$ regime. Once freed from a regime such as FIFO, storers may make full avail of the flexibility of being able to transfer title to gas within the pool.

\section{Homogeneity of Gas}

If any batch of a storer's gas retains deemed identity based upon the classification of that gas at injection, or by such other means as the twelve month evaluation and payment provision in section 8 of Schedule 1, reporting and administration become dramatically increased responsibilities. Therefore, if the gas in storage is treated as homogeneous, many of these problems and complications are avoided.

\section{Simplicity}

For both storers and a government to be encouraged to make the maximum use of storage, these features of storage ought to be as simple and readily determinable as possible:

(a) reporting and administration;

(b) pricing for royalty payments;

(c) calculating deductions from royalty payments; and

(d) assignment of storage rights.

\section{THE AGREEMENT}

In order to provide the flexibility to allow AEC to own and operate a fully diversified upstream storage facility, Alberta has chosen to ignore the stricture of Regulation 246/90, by entering into the Agreement, which provides far more operational provisions than simply the right to inject, store and remove gas. 
Terms and conditions of storage for AEC and all other "Storers" are contained in the body of the Agreement. Schedule 1 describes the storage pool the "Leased Zone" and "Location"; Schedule 2 sets out AEC's "Pre-1992 Stored Gas" Conditions and Schedule 3 is the pro forma Subscription Agreement for other Storers to enter into with Alberta and AEC.

\section{A. AUTHORITY FOR AGREEMENT}

The Lieutenant Governor in Council for the Province of Alberta has the authority to enter into the Agreement under the "General Powers of the Minister" found in section 9(a) of the Mines and Minerals Act.

\section{B. APPLICATION OF SECTION 8 OF SCHEDULE 1}

Section 8 of Schedule 1 will have limited application to AEC for AEC's gas already in storage on April 1, 1992. This application will end on March 31, 1993, for by that date, AEC will either have removed all gas stored prior to April 1,1992 and have paid Alberta royalty share at the actual sales price, or AEC will be deemed to have sold that gas at the end of twelve months following the month of original injection. Depending on AEC's removal of gas which AEC stored prior to April 1, 1992, some of AEC's reporting obligations contained in the Agreement may continue after March 31, 1993.

\section{Pre-1992 Stored Gas Applies to AEC Only}

AEC will be bound by section 8 of Schedule 1 for Pre-1992 Stored Gas; gas which AEC owned and injected prior to April 1, 1992 (the "Transition Date") and which AEC did not remove before that date. ${ }^{9}$ This section will not apply to AEC or any Storer which injects "Injection Gas" into the Leased Zone after the Transition Date, and which gas is then referred to as "Stored Gas." 10

\section{Pre-1992 Stored Gas Subject to FIFO}

AEC will be required to remove this Pre-1992 Stored Gas on a FIFO basis and pay Alberta for Alberta's royalty share of that gas, at the sales price realized after removal from storage or at a deemed sales price if that gas remains in storage for twelve months."

\section{CAP Does Not Apply to Pre-1992 Stored Gas}

If any of AEC's Pre-1992 Stored Gas remains in storage for twelve months, AEC will be subject to section 1(3)(b)(1) and 1(4) for the determination of the "fair value" of the deemed sale of that gas, as that expression is used in section 8 of Schedule $1 .^{12}$

\footnotetext{
Supra note 1, Schedule 2 sections 2.1 and 4.3.

Ibid. and Schedule 2 section 3.6.

Supra note 1, Schedule 2 sections 2.1 and 4.1 .

Supra note 9.
} 
4. AEC To Remove All Pre-1992 Stored Gas First

AEC will be required to remove all its Pre-1992 Stored Gas before AEC will be permitted to remove any Stored Gas which AEC injects on and after the Transition Date. $^{13}$

The removal requirements for AEC's gas will be in the following order:

(a) AEC's Pre-1992 Stored Gas until AEC's "Pre-1992 Stored Gas Account" is reduced to zero;

(b) AEC's Stored Gas, until AEC's "Stored Gas Account" is reduced to zero; and

(c) AEC's "Native Gas." ${ }^{14}$

\section{Storer's Over-nomination May Become AEC's Pre-1992 Stored Gas}

If a Storer removes more of that Storer's Stored Gas than that storer has injected since the latter of the Transition Date and the commencement of any "Company Agreement" for storage with AEC, that Storer's Stored Gas Account will be reduced to zero and AEC will be deemed to have removed its oldest, Pre-1992 Stored Gas which remains in storage, equal to that over-removed volume. ${ }^{15}$

\section{No Pre-1992 Stored Gas For Other Storers Will Be Possible}

AEC will be required to have removed or to have bought and added to its Stored Gas Account, all gas which any party injected into the Leased Zone prior to the Transition Date, or AEC will run the risk that Alberta will classify such injected gas as AEC's original gas in place: Native Gas. ${ }^{16}$

\section{The Deemed Sale Valuation after Twelve Months in Storage}

As all AEC's agreements with parties which injected gas into the Leased Zone prior to the Transition Date were of a one year term and all of which ended on that date, the twelve month deemed valuation and payment provision of section 8 of Schedule 1 did not come into effect. However, all those parties would have been subject to a FIFO removal and reporting regime and to the obligation to pay Alberta any Alberta royal share of that injected gas, at the sales price they obtained when they removed it from the Leased Zone. ${ }^{17}$

Supra note 1, section 2.1.13.

Ibid. and Schedule 2 sections 4.1 and 4.4.

Supra note 13.

Supra note 1 section 2.1.15 and Schedule 2 sections 3.2 and 3.3.

Supra note 1. Schedule 2. Section 8 of Schedule I will apply generally to injection for the purpose of storage in the absence of any specific terms in the Agreement to the contrary. AEC is specifically provided with the authority to store gas from the "Term Commencement Date" of January I, 1988 


\section{APPLICATION OF SECTION 17}

The Agreement provides that Injection Gas injected after the Transition Date, strictly for the purpose of storage, will be "injected for a purpose other than storage."18 Accordingly, section 17 will apply in principle for all "Injection Gas" injected, stored in and removed from the Leased Zone after the Transition Date, even though Alberta generally interprets this section to be applicable for injection of gas other than for the purpose of storage.

Contrarily, the Agreement specifically provides that "Section 17(1) and (2)...shall not apply to Pre-1992 Stored Gas" which will be subject to section 8 of Schedule 1 of Regulation 246/90. ${ }^{19}$

While Alberta has interpreted sections 1(3)(b)(iv) and 1(4) to apply to the determination of the value of gas for royalty payment purposes under section 17, that interpretation shall not apply under the Agreement. The Agreement applies a deemed valuation of "CAP" at the point of injection of Injection Gas.

\section{THE RIGHT TO STORE}

Sections 5.1 and 5.2 of the Agreement grant both AEC, and AEC on behalf of other Storers, the right to inject and store Injection Gas in the Leased Zone.

None of the Mines and Minerals Act, Regulation 246/90 and the "agreements" (Alberta Crown Leases) issued under that Act, grant the right to a "lessee" or any other person, to store gas within and under the "location" of a Lease.

Section 92(1) of the Mines and Minerals Act does not grant the right to store petroleum and natural gas but provides as follows:

92(1) A petroleum and natural gas lease grants in accordance with the terms and conditions of the lease the right to the petroleum and natural gas in the location that are the property of the Crown.

When you read section 54(1) of the Mines and Minerals Act in conjunction with section 26(1)(b) of the Oil and Gas Conservation Act, ${ }^{20}$ you may draw the conclusion that the right to store must be found elsewhere in that Act, Regulation 246/90 or in the Mines and Minerals Act. This is not the case, for these provisions are not designed to address true storage. They are designed to satisfy the needs for disposal wells and injection for the purposes of enhanced recovery. These sections read as follows:

54(1) A person has, as against the Crown in the Right of Alberta:

is Supra note 1 section 3.6.

19 Supra note 1 Schedule 2, section 5.4.

20 R.S.A. 1980 , c. $0-5$ as amended. 
(a) the right to use a well or drill a well for the injection of any substance into an underground formation, if he is required by or has the approval of the Energy Resources Conservation Board to do so....

26(1) No scheme for ...

(b) the processing or underground storage of gas...

shall be procceded with unless the Board, by order, has approved the scheme or any other terms or conditions that the Board prescribes.

Despite these sections in the two statutes, the grant clause under an Alberta Crown Lease does not provide the right to inject, store and remove gas from a location referred to in a lease.

The standard grant clause in an Alberta Crown Lease is as follows:

...insofar as the Crown has the right to grant the same the exclusive right to explore for, work, win and recover petroleum and natural gas within and under the lands more particularly described....

Despite the absence of a specific grant of a right to store gas within the lands which are subject to an Alberta Crown Lease, a reader of section 8 of Schedule 1 might be lead to believe that such a right must exist or that such right might be inferred from the application of that section. Again, this is not the case. In order to have the right to inject, store and remove natural gas in and from an Alberta Crown Lease, the lessee will need to obtain the written approval of Alberta for that operation, before that lessee will be able to make avail of section 8 of Schedule 1 .

Considerable care should be taken, concerning the making of an interpretation that a person may calculate and pay Alberta royalties under section 8 of Schedule 1, especially if that person has already obtained the ERCB's approval of a scheme for the underground storage of natural gas.

If that person has proceeded to pay Alberta royalties under section 8 of Schedule 1 , without having obtained Alberta's written approval for natural gas storage, the consequences may include the following:

(a) when Alberta conducts an audit of that person's Alberta royalty payments, Alberta may amend that person's royalty payment obligations, by requiring that person to calculate and pay Alberta royalties under section 17 , for the original injection months for those injected Alberta royalty volumes and effective at a "fair value", determinable for each month for which that person injected those injected Alberta royalty volumes;

(b) the same consequences as addressed in (a) above may occur, when that person has injected those Alberta royalty volumes, using what appears to be facilitating 
wording to inject and hence to store natural gas, as may be provided in a Unit Agreement to which Alberta is a party.

The right to inject natural gas, as may be found in a Unit Agreement to which Alberta is a party, is to permit the bound parties to maximize their potential to remove Unitized Substances from the Unitized Zone. This maximization of opportunity will be afforded these parties under the wording of their Alberta Crown Leases, which will permit the lessees to "work" the petroleum and natural gas, which they will have "explored for" and which they will be in the process of "winning" (sic). The injecting parties will be entitled to temporarily retain some of the injected natural gas in the Unitized Zone: this is an anticipated result of injection for enhanced recovery; it is not the vesting of a right to inject natural gas for the purpose of storage.

\section{E. "FREEHOLD ZONE"}

The Leased Zone includes three quarters of a section; the natural gas rights for which AEC owns in fee simple. The Agreement does not refer to rights in respect of storage of gas under these lands, although those lands will inevitably contain Stored Gas. For the term of the Agreement, this land is frozen within the Leased Zone for the purposes of recovering original gas in place under that land. ${ }^{21}$

\section{F. OBLIGATION TO PAY FOR THE ALBERTA ROYALTY SHARE}

Section 9.1 of the Agreement requires a Storer of Injection Gas which contains an Alberta royalty share, for which that Storer has not already made payment to Alberta and which that Storer stores after the Transition Date, to pay for that royalty share in the month of injection at the Storer's CAP. Section 2.1.1 of the Agreement defines CAP as the Corporate Average Price of the Storer for that month determined "in accordance with section 4.3.4 of the Gas Royalty Guidelines dated December, 1990, published by the Alberta Department of Energy."

\section{G. FUEL GAS WILL BE SUBJECT TO ALBERTA ROYALTY}

Section 16(4) of Regulation $246 / 90$ provides as follows:

$16(4)$ No royalty is payable to the Crown

(a) on natural gas or residue gas that is consumed for the purpose of gathering and processing natural gas that is

(i) derived from the same pool as the natural gas or residue gas consumed and

(ii) subject to the payment of royalty to the Crown... 
Two important points are found in Article 10 of the Agreement:

(a) only AEC may supply and consume gas as fuel for injecting and removing gas from the Leased Zone; ${ }^{22}$ and

(b) while AEC may consume fuel gas other than that containing an Alberta royalty share (such as purchased gas and AEC's Stored Gas once AEC has removed all AEC's Pre-1992 Stored Gas) ${ }^{23}$ if AEC consumes fuel gas containing an Alberta royalty share, such as gas from which AEC derives Injection Gas, AEC's Pre1992 Sales Gas or AEC's Native Gas, AEC will be required to pay for that royalty share at AEC's CAP for that month.

Article $10^{24}$ therefore supersedes section 16(4) of Regulation 246/90 even where AEC consumes Native Gas for fuel, so long as AEC consumes that gas for storage injection or removal purposes. For any period where AEC might be removing and selling Native Gas, AEC would be able to make avail of section 16(4) of Regulation 246/90 and the normal Gas Cost Allowance deductions, as if that Native Gas were not produced through an injection/removal well, subject to those limits on such deductions and consumed volumes as the Minister would ordinarily approve.

\section{H. NO DEDUCTIONS EQUIVALENT TO GCA}

The Agreement defines "Storage Costs" 25 as those costs which AEC incurs to inject Injection Gas into, store and remove gas (other than Native Gas) from, the Leased Zone and completes that definition by limiting those costs to the facilities AEC uses for that purpose at the AECO C Station.

When AEC calculates the royalty payable to Alberta on Alberta's royalty share of AEC's Injection Gas, AEC will not be permitted to apply those Storage Costs, as they are attributable to AEC's portion of all Injection Gas, as an additional Gas Cost Allowance deduction. ${ }^{26}$

A Storer's fees which are to be paid to AEC for storage rights or any portion of those fees which might be attributed as being that Storer's Storage Costs, will also be amounts which the Storer will not be entitled to deduct when determining the net amount of the Storer's royalty payments to Alberta. ${ }^{27}$

Supra note 1 , section 10.3 .

Supra note 1, section 2.1.14.

24

Supra note 1, Article 10. This Article does not restrict existing rights of Storers from making fuel gas and GCA deductions in calculating the royalty payable on Alberta's royalty share, to the extent the Storer incurs such costs and expenses prior to injecting Injection Gas into the Leased Zone. 
All previously existing and future entitlements for AEC and all other Storers to deduct Gas Cost Allowances which they incur to the point of injection into the Leased Zone, will remain unaffected. $^{28}$ By reason that all Alberta royalty share payments will be discharged as if a Storer had made a sale of all Injection Gas at the point of injection at that Storer's CAP, all Storage Costs and fees, and all costs of compressing and transporting that gas within, from and beyond the Leased Zone to the actual point of sale, will be the sole liability of the Storer. ${ }^{29}$

\section{LEASES AND AGREEMENT ARE INDEPENDENT}

Alberta has not chosen to issue Alberta Crown Leases for the Leased Zone or to amend the terms of the existing Leases in which the Leased Zone is contained. All conditions of storage are to be found in the Agreement and Regulation 246/90.

The placement of all additional contractual rights of storage in the Agreement is an important part of the structuring of this storage arrangement. In this manner, all matters particular to the Agreement and particular to each of the Alberta Crown Leases themselves, are kept separate, both as to administration and for contractual and statutory performance.

\section{J. SUBSCRIPTION AGREEMENTS}

The Agreement provides an attornment procedure for those parties which have contracted with AEC to have their gas stored in the Leased Zone. As the right to store for such a party is not contained in the Mines and Minerals Act or Regulation 246/90, the Agreement sets out the right in AEC to store third party gas in the Leased Zone and for third parties to have their gas stored for them by AEC in the Leased Zone. ${ }^{30}$

For a party to become a Storer, that party may do so for the injection of gas after the Transition Date, by satisfying these conditions precedent:

(a) the party shall enter into an agreement for storage with AEC in a form of which the Minister has already approved, for the purposes of AEC's providing firm or interruptible services of storage under the Agreement and which agreements are referred to as "Company Agreements"; $;$ " and

(b) the party shall enter into a "Subscription Agreement" in the form of that attached to the Agreement as Schedule 3. ${ }^{32}$

\footnotetext{
28 Supra note 22.

29 Supra note 1, section 10.1.3.

$30 \quad$ Supra note 1 , sections 5.1 and 5.2; infra note 59.

$31 \quad$ Supra note 1, section 12.1 and 12.3 .

$32 \quad$ Ibid. section 12.1 .
} 
By reason of AEC's retaining possession and control in law and in equity of the Leased Zone and all associated facilities, no Storer may assume the position of a true assignee or lessee of AEC's rights and obligations relating thereto.

Despite the Storer's entering into of a Subscription Agreement, the relationship between AEC and that Storer will be closer to that of bailment. The attornment to Alberta is to ensure the maximum flexibility for Alberta and the retention for Alberta of all the rights Alberta would have against AEC, relating to provisions now provided in the Agreement which might ordinarily be provided in Alberta legislation.

The form of Subscription Agreement is simple. The Storer is provided with those rights and obligations which Alberta made available to Storer's other than AEC in the Agreement; the Storers and permitted assignees agree to be bound thereby and the Storer consents to AEC's delivering a copy of that Storer's Company Agreement to Alberta, if so requested of $\mathrm{AEC}$ by the Minister. ${ }^{33}$

\section{K. ASSIGNMENT}

\section{Assignment by AEC}

To facilitate gas storage by Storers other than AEC, the Agreement provides rights for those Storers and will not require AEC to assign any of its storage rights for the Leased Zone to such Storers. ${ }^{34}$

AEC's rights of assignment under the Agreement are subject to prior Ministerial approval. ${ }^{35}$ Unlike the detailed qualification to the rights of the Minister to withhold his consent where a Storer other than AEC wishes to assign an interest in the Agreement, ${ }^{36}$ the Agreement is silent on the criteria which the Minister may require as conditions precedent to an assignment of all or part of AEC's storage rights under the Agreement.

\section{Assignment by a Storer other than AEC}

The Agreement has provided Storers other than AEC, with a clear, albeit detailed, set of conditions precedent for the obtaining of the Minister's consent to assignment, which if they satisfy, will enable them to assign their rights under the Agreement and a Subscription Agreement. ${ }^{37}$

To assign all or a partial interest in a Storer's rights under the Agreement, the Storer will have to satisfy the following conditions to the Minister's satisfaction: 
(a) the Storer shall assign both its interests in the Agreement and its Subscription Agreement; ${ }^{38}$

(b) if the Storer assigns to the assignee all its Stored Gas, the Storer shall only be able to assign all its interests in the Agreement and its Subscription Agreement; ${ }^{39}$

(c) the Storer shall only be able to assign a partial interest in the Agreement and its Subscription Agreement if it makes that assignment equal or shorter than the balance of the term of its current Subscription Agreement; ${ }^{40}$

(d) the Storer shall only make an assignment to one level of assignee; this means the assignee shall be prohibited from making any assignment to any other party of all or a partial interest which the assignee may acquire in the Agreement and the initial Storer's Subscription Agreement; ${ }^{41}$

(e) the Storer shall cause notice to be given to the Minister of the assignment in the Agreement and the Subscription Agreement; ${ }^{42}$

(f) to accompany that notice to the Minister the Storer shall cause to be delivered to the Minister an assumption of the Storer's obligations under the Agreement and its Subscription Agreement; ${ }^{43}$

(g) the Storer shall assign a corresponding interest in the Company Agreement between AEC and that Storer; ${ }^{44}$ and

(h) when a Storer and its assignee sign a partial assignment in the Agreement and a Subscription Agreement, the Storer shall also cause to be delivered to the Minister a copy of that partial interest assignment, the form of which shall be satisfactory to the Minister. ${ }^{45}$

If the Storer performs all these provision to the Minister's satisfaction, the Minister may not unreasonably withhold his consent to that assignment. ${ }^{46}$

Although the Storer will be required to carefully document the terms of any assignment, the business of the Storer need not be unduly delayed by a cumbersome administrative consent procedure.

$\begin{array}{ll}38 & \text { Supra note 1, section 14.2.2. } \\ 39 & \text { Supra note 1, section 14.2.4.1. } \\ 40 & \text { Supra note 1, section 14.2.4.2. } \\ 4 & \text { Supra note 1, section 14.2.1. } \\ 42 & \text { Supra note } 36 . \\ 43 & \text { Ibid. } \\ 4 & \text { Supra note } 1 \text {, section 14.2.3. } \\ 45 & \text { Supra note } 1, \text { section 14.2.5. } \\ 46 & \text { Supra note } 36 .\end{array}$


The Minister need not respond to the Storer and AEC. If the Minister has not given the Storer and AEC notice indicating his refusal or consent within 30 days of the Storer's satisfying all the conditions precedent to the Minister's consent, the Minister's consent will be deemed to have been provided. ${ }^{47}$

\section{CONTINUING RIGHTS OF ALBERTA}

In addition to Alberta's statutory controls as they already exist, Alberta has provided itself with three levels of performance control and protection in the Agreement.

\section{Administrative and Performance Controls}

The circumstances under which the Minister may provide his consent or input to the operations of AEC, its Storers and their assignees are:

(a) the Minister may disagree with the reporting of volumes of gas injected or removed from the Leased Zone and he may redetermine those volumes, which determination will prevail; ${ }^{48}$

(b) the Minister has the right to require $\mathrm{AEC}$ to deliver to him the pro forma Company Agreements as AEC may change them over time, to approve of the form of those instruments and to request AEC deliver copies of the signed Company Agreements; ${ }^{49}$

(c) the Minister may approve the form of assignments between Storers other than AEC, and their assignees, when those Storers assign partial interests in the Agreement and their Subscription Agreements; ${ }^{50}$ and

(d) the Minister is an integral part of the assignment process for AEC and all other Storers: failure to comply with that process will specifically exclude the Minister from becoming bound by the purported assignment. ${ }^{\text {st }}$

\section{Rights to Amend the Terms of the Agreement}

Without needing to rely on any general authority under the Mines and Minerals Act and Regulation 246/90 vested in either the Minister or the Lieutenant Governor in Council, the Agreement enables the Minister to use discretionary authority in the following situations:

(a) except for being restricted from requiring a signing consideration at the time of renewing the term of the Agreement, the Minister may specify new terms and

Supra note 1, section 14.3.

Supra note 1, section 8.3 .

Supra note 1, sections 12.2 and 12.4; Schedule 3 section 4.4 .

Supra note 45.

Supra note 1, section 14.2.5 and 14.4. 
conditions to the Agreement effective April 1,2003 and at the end of each five year term thereafter; ${ }^{52}$

(b) in addition to Alberta's rights to prescribe royalties by legislation, Alberta specifically reserves its rights to prescribe royalty for Injection Gas, natural gas from which the Injection Gas is obtained, Stored Gas and Native Gas; ${ }^{53}$

(c) the Minister ensures AEC's active use of the Leased Zone by requiring AEC to inject a "Minimum Quantity" of Injection Gas each twelve months (on a rolling year basis); the Minister may, by notice to AEC and effective upon AEC's receipt of that notice, amend that Minimum Quantity for the next twelve months following AEC's receipt of that notice; ${ }^{54}$

(d) so long as the Minister gives all Storers 18 months' prior notice to a change, the Minister may re-establish the definition of CAP, to be effective five years after the Transition Date (April 1, 1997), at the end of the "Term" of the Agreement (April 1, 2003) and at the end of each subsequent term of five years of the Agreement. If the Minister gives such a notice and a Storer is not satisfied with the new definition, that Storer may withdraw from its Subscription Agreement or in AEC's situation, from the Agreement. ${ }^{5 s}$

\section{Right to Change the Agreement by Legislation}

The Agreement states that its provisions prevail over the existing legislation. ${ }^{56}$ If legislation is amended and those amendments conflict with the Agreement, the Agreement will be deemed amended to give affect to that legislation. ${ }^{57}$

\section{FEES TO ALBERTA FOR PROVIDING STORAGE RIGHTS}

In section 7.1 of the Agreement, Alberta has provided that AEC will pay an additional annual rental to that which AEC already pays for the rental on the location of the Leases covering the Leased Zone in an amount of $\$ 180,800$ per annum $(\$ 25.00 /$ hectare).

\section{N. NATIVE GAS AND CUSHION GAS}

The Agreement is notable for two provisions which are absent.

As Native Gas in place in the Leased Zone provided a sound base to commence storage operations, Alberta has not required AEC to have injected any cushion gas into the Leased

Supra note 1, sections 6.1 and 6.2.

Supra note 1, section 9.4 .

Supra note 1 , sections 2.1 and 15.2. "Minimum Quantity is $420 \mathrm{E}^{6} \mathrm{~m}^{3}$ of Injection Gas.

Supra note 1, section 15.6.

Supra note 1 , section 5.3

Supra note 1, section 3.4 . 
Zone. This relieves AEC from any burden to have "pressured-up the pool" prior to commencing storage operations. Without that potential liability, AEC has not incurred additional costs of storage which would likely have been absorbed by AEC and all other Storers.

Except in the situation of over-removal of Stored Gas, Alberta has not required AEC to produce any Native Gas during the currency of the Agreement. This materially improves AEC's reporting and administrative responsibilities and reduces AEC's overall costs of storage, for AEC retains control over whether or not AEC will produce any Native Gas during the currency of the Agreement. This is another potential cost for AEC which AEC has been able to avoid and which will improve the cost effectiveness of the Leased Zone for AEC and all other Storers.

When the Agreement comes to an end, any Stored Gas of AEC or any Storer which remains in the Leased Zone will revert to Native Gas. Alberta may terminate the Agreement on 365 days notice if an event of default is not rectified in the prescribed time. AEC may terminate the Agreement on 365 days notice without cause, if AEC is not in default at the time of giving notice. ${ }^{58}$

\section{CONCLUSION}

The Agreement will establish a precedent for royalty regulatory compliance for upstream gas storage in Alberta, which will be beneficial not only to AEC but also to Alberta and all other Albertan producers.

Storage will be "Pay as You Go." The spectre that Alberta will insist on applying a FIFO storage regime for all storage schemes which will involve multiple storers has all but been removed.

Flexibility in storage operations has been garnered for both AEC and Storers. AEC has established pro formas for the Company Agreements with Storers: one for interruptible storage rights; one for firm storage rights; and one for long term, firm storage rights. ${ }^{59}$ The short term pro forma agreements are for a one year term (April to March 31) and provide for a commodity charge for delivery of gas from storage. Firm storage requires the Storer to pay a demand charge in addition to the commodity charge. The assignment provisions of the Agreement will permit those producers which secure firm storage, to provide firm or interruptible storage to other producers. Those producers which secure Company Agreements directly with AEC will be able to assign the benefits of those storage rights to their industry participants.

s9 P.H. Davies, "Upstream Storage: Optimizing the Value of Gas Production" Insight Seminar "Gas Marketing: Optimization Strategies for Producers" Calgary, Alberta, May 25, 1992. 


\section{SCHEDULE A}

\section{Mineral Resources Division}

\section{NATURAL GAS STORAGE AGREEMENT}

Date of Issue: September 23, 1992

Term Commencement Date: January 1, 1988

THIS AGREEMENT made as of the Date of Issue

\section{BETWEEN:}

HER MAJESTY THE QUEEN in right of the province of Alberta, hereinafter called "Her Majesty," as represented by the Minister of Energy, hereinafter called the "Minister"

OF THE FIRST PART

$$
\text { - and - }
$$

ALBERTA ENERGY COMPANY LTD., hereinafter called "AEC," a body corporate, incorporated under the laws of Alberta and having its head office at the City of Edmonton, in the Province of Alberta

OF THE SECOND PART

\section{WHEREAS:}

1.0 AEC is the holder of certain rights to recover natural gas from the Leased Zone;

2.0 AEC wishes to acquire from Her Majesty the right for AEC to store gas in the Leased Zone on its own behalf and on behalf of others;

3.0 The Lieutenant Governor in Council by Order in Council dated September 23, 1992 and numbered O.C. 544/92 has authorized the Minister to enter into this Agreement and the Subscription Agreements referred to herein.

NOW THEREFORE the parties hereto agree as follows:

\subsection{Name of Agreement}

1.1 This Agreement may be referred to as the "Suffield Upper Mannville I Crown Storage Agreement." 


\subsection{Interpretation}

2.1 In this Agreement,

.1 "CAP" means, in respect of each Storer each Month, the amount determined as the Corporate Average Price of the Storer for the Month, in accordance with section 4.3.4 of the Gas Royalty Guidelines dated December, 1990 published by the Alberta Department of Energy;

.2 "Company Agreement" means a contract entered into by AEC with a person who wishes to become a Storer, whereby AEC undertakes to inject into, store within and recover or obtain from the Leased Zone on or after the Transition Date, gas on behalf of the person;

.3 "Energy Content" means, in relation to gas, the energy, expressed in gigajoules, that would be released by the complete combustion of the gas initially free of all water vapour and at a temperature of 15 degrees Celsius, at a constant pressure of 101.325 kilopascals with the products of combustion cooled to 15 degrees Celsius and all water formed by the combustion reaction condensed to the liquid state;

.4 "Freehold Zone" means the zone described under the heading "Leased Zone" in Schedule 1, to the extent the zone underlies the tract in Alberta described as the west half and the southeast quarter of Section 26, Township 16, Range 9, west of the 4th Meridian;

.5 "Injection Gas" means residue gas obtained from natural gas initially recovered other than from the Leased Zone pursuant to agreements or otherwise;

.6 "Leased Zone" means the zone described under the heading "Leased Zone" in Schedule 1 to this Agreement, to the extent the zone underlies the Location;

.7 "Leases" means the agreements under the Mines and Minerals Act, other than this Agreement, held by AEC as lessee up to the Term Commencement Date, granting AEC the right to win, work and recover natural gas, inter alia, from the Leased Zone;

.8 "Location" means the tracts of land described under the heading "Description of Location" in Schedule 1;

.9 "Minimum Quantity" means the volume of Injection Gas expressed in $E^{6} \mathrm{~m}^{3}$ specified in a notice given by the Minister to AEC under section 15.2, provided however that from and after the Transition Date until the Minister gives the first of such notices to AEC, "Minimum Quantity" means $420 \mathrm{E}^{6} \mathrm{~m}^{3}$ of Injection Gas; 
.10 "Month" means each month of the Term;

.11 "Native Gas" means natural gas that is or was naturally present in the Leased Zone;

.12 "Regulation" means the Natural Gas Royalty Regulation (Alta. Reg. 246/90) as amended;

.13 "Sales Gas" means, in respect of each Storer, a marketable gas stream not reinjected into the Leased Zone, recovered, or obtained by processing natural gas recovered, from the Leased Zone on behalf of the Storer during the Term while

.1 the Stored Gas Account of the Storer is greater than zero, in the case of Storers other than AEC, or

.2 the Stored Gas Account of AEC is greater than zero and the Pre-1992 Stored Gas Account of AEC described in Schedule 2 is zero, in the case of AEC;

.14 "Storage Costs" means all costs and expenses incurred by AEC

.1 to

.1 inject Injection Gas into,

.2 store gas in, or

.3 recover or obtain gas, other than Native Gas, from

the Leased Zone, whether on its own behalf or on behalf of others, and

.2 at or about AEC's AECO C Station located on lands described as SE/4 04-019-09 W4M and in particular, from the "Storage Injection Point," being a meter station owned and identified by NOVA as AECO C Sales \#3473 (AECO Interconnection \#3880) and to the "Storage Withdrawal Point," being a meter station owned and identified by NOVA as AECO C Receipt \#1332 (AECO Interconnection \#3880), both of which Points are located on the above described lands;

.15 "Stored Gas" means, in respect of each Storer, the Injection Gas injected into the Leased Zone pursuant to this Agreement on behalf of the Storer on or after the Transition Date, and in the case of AEC includes any gas injected into the Leased Zone on or after the Term Commencement Date and before the Transition Date on behalf of a person other than AEC or Her Majesty that as of the time immediately preceding the Transition Date 
.1 has been purchased by AEC from that person, and

.2 remains within the Leased Zone;

.16 "Stored Gas Account" at any time means, in respect of each Storer, the volume of the Storer's Stored Gas up to that time, less the volume of the Storer's Sales Gas recovered or obtained up to that time that is deemed under section 8.1 to have been any of the Storer's Stored Gas;

.17 "Storer" means AEC and each person who is a party to a subsisting Subscription Agreement entered into with Her Majesty and AEC, and for greater certainty, includes an assignee of an interest in a Subscription Agreement in respect of the assignment of which the Minister has consented under Article 14.0;

18 "Subscription Agreement" means a contract entered into by any person with Her Majesty and AEC in the form attached hereto as Schedule 3;

.19 "Term" means, unless this Agreement is sooner cancelled under section 15.1, 15.7.1 or 15.9, the initial term and any renewal term of this Agreement as specified in Article 6;

.20 "Term Commencement Date" means the date shown as such on the first page of this Agreement;

.21 "Transition Date" means 8:00 a.m. on April 1, 1992; and

.22 "Year of the Term" means the Months contained in each period of 12 consecutive months that commences with each April 1 that occurs during the Term.

2.2 In this Agreement, a reference to a statute referred to in section 3.1 shall be construed as a reference to

.1 that statute, as amended from time to time,

.2 any replacement of all or part of that statute from time to time enacted by the Legislature of the Province of Alberta as amended from time to time, and

.3 any regulations, orders, directives, by-laws or other subordinate legislation from time to time made under any statute referred to in section 2.2 .1 or 2.2.2, as amended from time to time.

2.3 In this Agreement,

.1 a reference to the Minister includes a deputy minister of the Department of Energy of the Province of Alberta and any person authorized by the Minister or deputy minister to act on behalf of the Minister, 
.2 whenever the singular, masculine or neuter is used, the same shall be construed as meaning plural, feminine or body politic or corporate and vice versa where the context so requires,

.3 references herein to any contract or instrument, including this Agreement, shall be deemed to be references to the contract or instrument as varied, amended, modified, supplemented or replaced from time to time, and

.4 "this Agreement," "herein," "hereby," "hereof," "hereto," "hereunder" and similar expressions mean or refer to this Agreement and any amendment hereto, and the expressions "Article" and "section" followed by a number mean and refer to the specified article and section of this Agreement.

2.4 The division of this Agreement into Articles and sections, the provision of a table of contents and the insertion of headings are for convenience of reference only and shall not affect the construction or interpretation hereof.

2.5 This Agreement shall be governed by and construed in accordance with the laws in force in the Province of Alberta.

2.6 The following Schedules are attached hereto and deemed to be a part hereof:

Schedule 1 Leased Zone and Description of Location

Schedule 2 AEC's Pre-1992 Gas Conditions

Schedule 3 Form of Subscription Agreement

If there is a conflict or inconsistency between any provision of the body of this Agreement and any Schedule or anything contained in a Schedule, the provision of the body of this Agreement shall prevail.

\subsection{Application of Act and Regulations}

3.1 Each Storer shall comply with the provision of

.1 the Mines and Minerals Act, and

.2 any other statutes of the Legislature of Alberta that prescribe, apply to or affect the rights and obligations of, in the case of AEC, a lessee of natural gas rights from Her Majesty and, in the case of each Storer including AEC, a holder of underground storage rights from Her Majesty, or that relate to or affect the conduct of any of the operations or activities under this Agreement,

as amended from time to time. 
3.2 The provisions of the statutes referred to in section 3.1 shall be deemed to be incorporated in this Agreement.

3.3 In the event of a conflict that exists on the Date of Issue hereof between a provision of this Agreement and a provision referred to in section 3.1, the provision of this Agreement shall prevail, unless otherwise expressly provided herein.

3.4 In the event of a conflict that comes into existence after the Date of Issue hereof between a provision of this Agreement and a provision referred to in section 3.1, the provision referred to in section 3.1 shall prevail, notwithstanding any provision to the contrary in this Agreement.

3.5 Except to the extent otherwise provided herein,

.1 the Regulation applies to AEC, Storers, Injection Gas injected into the Leased Zone, gas recovered from the Leased Zone, and gas obtained by processing natural gas recovered from the Leased Zone, and

.2 definitions used in the Regulation have the same meaning in this Agreement.

3.6 Notwithstanding sections 5.1 and 5.2, any Injection Gas injected into the Leased Zone pursuant to this Agreement on or after the Transition Date shall, unless the Minister otherwise specifies in writing, be treated for the purposes of the Regulation as though it were injected for a purpose other than storage.

\subsection{AEC's Pre-1992 Gas}

4.1 The terms and conditions of Schedule 2 apply to, and bind Her Majesty and AEC as though fully set out herein.

\subsection{Rights Granted}

5.1 Her Majesty hereby grants to AEC, insofar as the Crown has the right to grant the same and subject to the terms and conditions hereof, the exclusive right to inject into and store within the Leased Zone, Injection Gas, whether on AEC's own behalf or on behalf of any other Storers, to have and enjoy the same for the Term.

5.2 Her Majesty hereby grants to each Storer other than AEC, insofar as Her Majesty has the right to grant the same and subject to the terms and conditions hereof and of the Subscription Agreement between the Storer, Her Majesty and AEC, the right to have Injection Gas of the Storer injected into and stored within the Leased Zone by AEC on the Storer's behalf, to have and enjoy the same for the term of the Subscription Agreement.

5.3 AEC shall not drill a well to, permit a well to be drilled to, recover natural gas from nor permit natural gas to be recovered from the Freehold Zone. 
5.4 From and after the Transition Date, AEC shall not inject Injection Gas into the Leased Zone on behalf of anyone other than AEC, Her Majesty or a Storer.

\subsection{Term}

6.1 The term of this Agreement commences on the Term Commencement Date and ends on March 31, 2003 and is renewable for further terms of five years each for so long as AEC is not in default under, and is conducting storage operations pursuant to, this Agreement, subject to early cancellation of this Agreement during the initial or any renewal term under section $15.1,15.7 .1$ or 15.9 and, in the case of renewal, to the Mines and Minerals Act and the terms and conditions specified by the Minister at the time the renewal is granted.

6.2 The terms and conditions of renewal referred to in section 6.1 shall not include any monetary consideration solely for the granting of that renewal, other than any increase in the storage facility charge.

\subsection{Storage Facility Charge}

7.1 AEC shall pay to Her Majesty for the Year of the Term commencing April 1, 1992 and for each subsequent Year of the Term, a storage facility charge of $\$ 25.00$ per hectare for each hectare of the Location, payable on or before the execution of this Agreement for the first of those Years of the Term and on or before April 1 of each Year of the Term thereafter.

7.2 For the purposes of this Agreement the Location shall be deemed to contain 7,232 hectares.

\subsection{Order of Reproduction}

8.1 Any volume of Sales Gas recovered or obtained by or on behalf of a Storer while the Stored Gas Account of the Storer is greater than zero shall be deemed to be the equivalent volume of Stored Gas of the Storer injected into the Leased Zone that has not by virtue of this section, been deemed to have been previously so recovered or obtained.

8.2 Each Storer shall, after the end of each Month, determine for the Month

.1 the volume of Sales Gas recovered or obtained on behalf of the Storer in the Month, and

.2 the volume of gas recovered, or obtained from natural gas recovered, from the Leased Zone during the Month on behalf of the Storer while the Stored Gas Account of the Storer is zero. 
8.3 If the Minister disagrees with any determination made by a Storer under section 8.2, the Minister may make the determination in accordance with section 8.1 and his determination shall prevail over any determination by the Storer.

\subsection{Royalty}

9.1 Subject to sections 15.6, 15.7 and 15.8, each Storer shall, in relation to Her Majesty's royalty share of Injection Gas injected on or after the Transition Date into the Leased Zone on behalf of the Storer in a Month, pay to Her Majesty, at the time and in the manner specified in the Regulation, the excess of the product of the Energy Content of the royalty share and the CAP of the Storer for the Month, over the costs and allowances consented to by the Minister under the Regulation in respect of the royalty share.

9.2 Her Majesty's royalty share of any Native Gas recovered or obtained in a Month by AEC shall be sold, consumed or otherwise disposed of by AEC on Her Majesty's behalf along with the balance of that Native Gas.

9.3 AEC shall, in accordance with the Regulation pay Her Majesty in relation to Her Majesty's royalty share of Native Gas recovered or obtained in a Month, the amount of money determined in accordance with the Regulation for such Native Gas as though the royalty share was volumes sold that Month.

9.4 Nothing in this Agreement shall derogate from the right of Her Majesty to prescribe royalty in respect of Injection Gas, natural gas from which the Injection Gas is obtained, Stored Gas and Native Gas.

\subsection{Storage Costs and Her Majesty's Consumed Gas}

10.1 Each Storer acknowledges and agrees that Her Majesty will not consent to be liable and shall not be liable for

\section{.1 any Storage Costs,}

.2 any costs incurred by the Storer for fees paid for the right to have gas stored on its behalf in the Leased Zone, and

.3 any other costs relating to gas recovered or obtained from the Leased Zone, arising after such recovery or obtaining of the gas from the Leased Zone, other than the Native Gas.

10.2 Nothing in section 10.13 precludes AEC from entitlement to the costs and allowances incurred by it to gather, compress or process Her Majesty's royalty share of Native Gas, that are consented to by the Minister under the Regulation. 
10.3 Notwithstanding section 16(4)(a) of the Regulation, AEC shall, in accordance with this Agreement and the Regulation, pay Her Majesty in respect of

.1 the portion if any, of

.1 gas from which Injection Gas is obtained, or

.2 Pre-1992 Sales Gas, as defined in Schedule 2,

that is Her Majesty's royalty share, and

.2 Her Majesty's royalty share of Native Gas,

consumed by AEC (hereinafter called "Her Majesty's Consumed Gas") in a Month with respect to the injection of Injection Gas into, the storage of gas in, or the recovery or obtaining of gas from the Leased Zone, whether on its own behalf or on behalf of others, the excess of the product of the Energy Content of Her Majesty's Consumed Gas for the Month and AEC's CAP for the Month, over the costs and allowances consented to by the Minister under the Regulation in respect of Her Majesty's Consumed Gas for the Month.

10.4 AEC may only consume AEC's gas (including Her Majesty's royalty share thereof, if any) for the purposes specified in section 10.3, but nothing in section 10.3 precludes AEC from consuming AEC gas other than gas containing Her Majesty's Consumed Gas for the purposes specified in that section.

\subsection{Records}

11.1 Each Storer shall maintain the records and submit the reports required by the Regulation to be maintained and submitted regarding the Storer's Injection Gas injected into the Leased Zone during the Term and shall maintain such additional records and submit such other reports as the Minister may require for the purposes of this Agreement.

\subsection{Subscription Agreement}

12.1 Any person other than AEC who wishes to have Injection Gas injected and stored on its behalf by AEC in the Leased Zone on or after the Transition Date and who has entered into a Company Agreement with AEC in a form approved under section 12.3, may enter into a Subscription Agreement with Her Majesty and AEC

12.2 So long as a person other than AEC is a party to a subsisting Subscription Agreement between that person, Her Majesty and AEC, the person shall be a Storer for the purposes of this Agreement and, subject to the terms and conditions of this Agreement and of the Subscription Agreement shall 
.1 have all the rights and benefits to hereunder of a Storer other than AEC, including the right to have, on or after the Transition Date, its Injection Gas injected into, Stored Gas stored within and Sales Gas recovered or obtained from the Leased Zone on its behalf by AEC, and

.2 be liable for all the obligations of a Storer other than AEC under this Agreement and the Subscription Agreement.

12.3 AEC shall obtain the Minister's approval for each pro forma contract under which AEC wishes to undertake to inject into, store within and recover or obtain from, the Leased Zone, gas on behalf of any other person, and for each amendment to such pro forma contract before any contract in at form or amended form as the case may be, is entered into by AEC with such other person.

12.4 AEC shall provide the Minister with a copy of any Company Agreement requested by the Minister as soon as possible after receiving the request.

\subsection{Indemnification}

13.1 AEC shall indemnify and save harmless Her Majesty against

.1 all actions, claims and demands brought or made against Her Majesty by reason of anything done by $A E C$, on its own behalf or on behalf of any other person on whose behalf it has injected gas into the Leased Zone, in the exercise or purported exercise of the rights granted under this Agreement, and

.2 all losses, damages, costs, charges and expenses that Her Majesty sustains or incurs in connection with any action, claim or demand referred to in section 13.1.1.

\subsection{Assignment}

14.1 A Storer shall not, without the prior consent of the Minister, assign

.1 any of its interest in this Agreement or a Subscription Agreement, or

.2 any of the rights or obligations of the Storer under this Agreement or a Subscription Agreement.

14.2 The Minister shall not unreasonably withhold consent under section 14.1 of an assignment by a Storer other than AEC, of the Storer's interest in this Agreement and the Subscription Agreement to which the Storer is a party if

.1 the Storer is the Storer named in the Subscription Agreement,

.2 notice of the assignment is given to the Minister, accompanied by an assumption by the assignee in a form satisfactory to the Minister of the 
Storer's obligations under this Agreement and the Subscription Agreement in respect of the interest assigned,

.3 a corresponding interest in the Company Agreement that is in effect between the Storer and AEC and referred to the Subscription Agreement is assigned to the assignee,

.4 the interest assigned is

.1 the entire interest of the Storer in this Agreement and the Subscription Agreement, and includes the Storer's interest in all Stored Gas of the assigning Storer remaining within the Leased Zone, or

.2 a partial interest of the Storer in this Agreement and the Subscription Agreement that does not exceed in duration the remaining term of the Company Agreement referred to in the Subscription Agreement, and

.5 the assignment is in a form approved by the Minister and a copy is delivered to the Minister upon execution in the case of an assignment of a partial interest referred to in section 14.2.4.2.

14.3 The Minister shall be deemed to have consented to an assignment under section 14.1 in respect of which he is not entitled to unreasonably withhold consent under section 14.2, if he has not given the assigning Storer and AEC notice indicating his consent or refusal of consent within 30 days after all the conditions for consent indicated in section 14.2 applicable to the assignment have been satisfied.

14.4 Any assignment of an interest in this Agreement or a Subscription Agreement that has not been consented to by the Minister under section 14.1 shall not be binding on Her Majesty.

\subsection{Cancellation}

15.1 The Minister may cancel this Agreement and every Subscription Agreement by giving AEC not less than 365 days notice of such cancellation, if,

.1 subject to section 15.4, AEC fails to comply with a provision of this Agreement or with a provision referred to in section 3.1,

.2 AEC on its own behalf and on behalf of other Storers, injects less than the Minimum Quantity of Injection Gas into the Leased Zone during any period of 12 consecutive Months of the Term, or

.3 AEC ceases to have the exclusive right to win, work and recover natural gas from the whole of the Leased Zone and Freehold Zone. 
15.2 The Minister may, from time to time by notice given to AEC, specify the volume, expressed in $\mathrm{E}^{6} \mathrm{~m}^{3}$, of Injection Gas that from the date of the notice, comprises for the purpose of section 15.1.2, the Minimum Quantity of Injection Gas that must be injected into the Leased Zone during any period of 12 consecutive Months of the Term.

15.3 The Minister may cancel a Subscription Agreement by giving not less than 365 days notice of such cancellation to AEC and the Storer who is a party to the Subscription Agreement if,

.1 subject to section 15.5 , the Storer has failed to comply with a provision of this Agreement, a provision referred to in section 3.1, or a provision of the Subscription Agreement, or

.2 the Company Agreement referred to in the Subscription Agreement and entered into by AEC with the Storer is not in a form approved by the Minister under section 12.3 , or

.3 the Company Agreement referred to in the Subscription Agreement expires and is not extended or replaced by other Company Agreement between AEC and the Storer within the period of time specified in a notice given by the Minister to AEC requiring its extension or replacement.

15.4 The Minister may not cancel this Agreement and every Subscription Agreement pursuant to section 15.1.1 unless

.1 he has given notice to AEC stating the nature of the failure and stating that the Minister will cancel this Agreement and every Subscription Agreement, if

.1 the failure is not rectified before the expiration of the 30 -day period following the date of the notice, or

.2 rectification of the failure does not commence within that 30-day period and proceed with due diligence thereafter, if the failure cannot reasonably be rectified within that 30 -day period, and

.2 the failure is not rectified within the 30-day period, or, in the case of a failure referred to in section 15.4.1.2, rectification of the failure does not commence within that 30-day period or does not proceed with due diligence thereafter.

15.5 The Minister may not cancel a Subscription Agreement pursuant to section 15.3.1 unless

.1 he has given notice to AEC and the Storer who is a party to the Subscription Agreement stating the nature of the failure and stating that the Minister will cancel the Subscription Agreement if 
.1 the failure is not rectified before the expiration of the 30-day period following the date of the notice, or

.2 rectification of the failure does not commence within that 30-day period and proceed with due diligence thereafter, if the failure cannot reasonably be rectified within that 30 -day period, and

.2 the failure is not rectified within the 30-day period, or, in the case of a failure referred to in section 15.5.1.2, rectification of the failure does not commence within that 30 -day period or does not proceed with due diligence thereafter.

15.6 The Minister may, on or before

.1 September 30, 1995, or

.2 the eighteenth Month prior to the last day of the initial or any renewal term of this Agreement,

give every Storer notice that the Minister intends to amend, effective

.3 April 1, 1997, in the case of a notice given under section 15.6.1, or

.4 the first day of the next renewal term following the giving of the notice, in the case of a notice given under section 15.6.2,

the definition of CAP in section 2.1.1 and the time and manner in which payments under section 9.1 are required to be made by Storers, such notice to specify the amendments intended to be made by the Minister.

15.7 Upon receiving a notice under section $\mathbf{1 5 . 6}$

.1 AEC may, by giving notice to Her Majesty and every Storer other than AEC on or before the last day of the sixth Month following that in which the notice under section 15.6 was received, cancel this Agreement and every Subscription Agreement effective

.1 March 31, 1997, in the case of a notice received under section 15.6.1, or

.2 the last day of the then current term of this Agreement, in the case of a notice received under section 15.6.2, and

.2 each Storer other than AEC may, by giving notice to Her Majesty and AEC on or before the last day of the sixth Month following that in which the notice under section 15.6 was received, cancel its Subscription Agreement effective

.1 March 31, 1997, in the case of notice received under section 15.6.1, or 
.2 the last day of the then current term of this Agreement, in the case of a notice received under section 15.6.2.

15.8 If AEC has not given Her Majesty notice under section 15.7 to cancel this Agreement and every Subscription Agreement, this Agreement shall be deemed to be amended effective April 1, 1997 or the date described section 15.6.3, as the case may be, in accordance with the Minister's notice given under section 15.6.

15.9 AEC may, if it is not in default under this Agreement, cancel this Agreement and every Subscription Agreement by giving Her Majesty and every Storer not less than 365 days notice of such cancellation.

15.10 Notwithstanding any provision hereof, AEC shall not

.1 inject any Injection Gas into the Leased Zone, whether on its own behalf or on behalf of any other Storer, after receiving notice of cancellation of this Agreement and every Subscription Agreement pursuant to section 15.1 or giving notice of such cancellation pursuant to section 15.7.1 or 15.9, and

.2 inject any Injection Gas into the Leased Zone on behalf of a Storer other than AEC, after receiving notice under section 15.3 or 15.7 .2 of cancellation of the Subscription Agreement to which the Storer is a party.

15.11 Any Stored Gas of a Storer that remains the Leased Zone after this Agreement or the Subscription Agreement of the Storer is cancelled in accordance with this Agreement is deemed to be Native Gas.

\subsection{Notices}

16.1 All notices, consents, requests and other documents authorized or required to be given pursuant to this Agreement or a Subscription Agreement shall be in writing and either delivered by hand, mailed by registered or certified first class air mail, postage prepaid, or sent by telecommunication as follows:

.1 In the case of Her Majesty

Minister of Energy Fax: 427-7737

c/o Deputy Minister, Energy

Department of Energy

10th Floor, Petroleum Plaza North

9945 - 108 Street

Edmonton, Alberta

T5K 2G6 
.2 In the case of AEC

Manager, Natural Gas Marketing

Alberta Energy Company Ltd.

639 - 5 Avenue S.W.

Calgary, Alberta

T2P 0M9

Fax: $266-8180$

.3 In the case of each Storer other than AEC, the address indicated for the Storer in the Subscription Agreement to which the Storer is as party,

and any notice, consent, request or other document so given shall be deemed to have been given and received, if delivered, on the day on which it was delivered, and, if mailed, on the tenth business day following the day it was mailed, and, if sent by telecommunication, on the first business day following the day it was dispatched. No other document hereunder during any party shall mail any notice, consent, request or other document hereunder during any period in which Canadian postal workers are on strike or if any such strike is imminent and may be anticipated to affect normal delivery thereof. A party may change its address for the receipt of notices, consents, requests and other documents at any time by giving notice of that change to the other parties.

16.2 Notwithstanding the requirements of this section as to the use of registered or certified first class mail, any routine reports required by this Agreement to be submitted by one party to another party at specified times may be sent by first class mail and if any party which should have received such reports pursuant to this Agreement fails to receive such reports on time, it shall so notify the sending party, in which event another copy of those reports shall be sent promptly by registered or certified first class mail.

\subsection{General}

17.1 No waiver on behalf of Her Majesty of any breach of any of the terms or conditions contained in this Agreement shall take effect or be binding upon Her Majesty unless the waiver is expressed in writing by the Minister, and any waiver so expressed shall not limit or affect Her Majesty's rights with respect to any other or future breach.

17.2 This Agreement is granted upon the condition that AEC and each Storer agrees to waive and hereby waives all rights, prerogatives, privileges and immunities that would otherwise exempt it from compliance with any of the provisions of the statutes referred to in section 3.1.

17.3 Any person authorized in writing by the Minister to do so may exercise the rights and powers of Minister under and for the purposes of this Agreement, including without limitation, the execution of Subscription Agreements on behalf of Her Majesty. 
17.4 This Agreement does not create any implied covenant or implied liability on the part of Her Majesty.

IN WITNESS WHEREOF Her Majesty and AEC have executed this Agreement as of the Date of Issue.

HER MAJESTY THE QUEEN IN RIGHT OF THE

PROVINCE OF ALBERTA, as represented by the

Minister of Energy

ALBERTA ENERGY COMPANY LTD. 
Schedule 2 to the

Suffield Upper Mannville I

Crown Storage Agreement

AEC's Pre-1992 Gas Conditions

\subsection{Interpretation}

1.1 In this Schedule

.1 "Agreement" means the Suffield Upper Mannville I Crown Storage Agreement, including the Schedules thereto;

.2 "Pre-1992 Sales Gas" means a marketable gas stream not reinjected into the Leased Zone, recovered, or obtained by processing natural gas recovered, from the Leased Zone during the Term by AEC on its own behalf while the Pre-1992 Stored Gas Account is greater than zero;

.3 "Pre-1992 Stored Gas" means the Injection Gas injected into the Leased Zone by AEC on its own behalf before the Transition Date;

.4 "Pre-1992 Stored Gas Account" at any time means the volume of Pre-1992 Stored Gas up to that time, less the volume of Pre-1992 Sales Gas recovered or obtained up to that time that is deemed under section 4.1 to have been Pre-1992 Stored Gas;

1.2 Unless otherwise expressly provided in this Schedule,

.1 terms defined in the Agreement have the same meaning when used in this Schedule, and

.2 the expressions "Article" and "section" followed by a number mean, when used in this Schedule, the specified article or section of this Schedule.

\subsection{Application of the Act and Regulation}

2.1 Any Injection Gas injected into the Leased Zone pursuant to this Agreement before April 1, 1992 shall, unless the Minister otherwise specifies in writing, be deemed to be injected for the purpose of storage and shall not for the purposes of the Regulation, comprise "injected royalty-paid volumes," "reproduced royalty-paid volumes" and "injected royalty-waived volumes." 


\subsection{Rights Granted}

3.1 Insofar as Her Majesty has the right to grant the same and subject to the terms and conditions of the Agreement, Her Majesty hereby grants to AEC for the part of the Term preceding the Transition Date, the right to inject into, store within and recover or obtain from, the Leased Zone, gas on behalf of any other person.

3.2 Notwithstanding section 3.1, AEC shall ensure that there is not, immediately prior to the Transition Date, any gas within the Leased Zone that belongs to anyone other than AEC or Her Majesty.

3.3 Any gas within the Leased Zone that belongs to anyone other than AEC or Her Majesty that remains within the Leased Zone immediately prior to the Transition Date shall thereafter be deemed to be Native Gas.

\subsection{Order of Reproduction}

4.1 Any volume of Pre-1992 Sales Gas recovered or obtained while the Pre-1992 Stored Gas Account is greater than zero shall be deemed to be the equivalent volume of the earliest Pre-1992 Stored Gas to have been injected into the Leased Zone that has not by virtue of this section, been deemed to have been previously so recovered or obtained.

4.2 Her Majesty's royalty share of any volume of Pre-1992 Sales Gas referred to in section 4.1 is the same proportion of that Pre-1992 Sales Gas as Her Majesty's royalty share of the Pre-1992 Stored Gas that the Sales Gas is deemed under section 4.1 to be, is of that Pre-1992 Stored Gas.

4.3 Nothing in this Agreement precludes the operation of section 8 of Schedule 1 of the Regulation in relation to Pre-1992 Stored Gas.

4.4 Any volume of gas recovered, or obtained from natural gas recovered, from the Leased Zone

.1 on behalf of a Storer other than AEC while the Stored Gas Account of the Storer is zero and

.1 the Pre-1992 Stored Gas account is greater than zero, shall be deemed to be Pre-1992 Sales Gas,

.2 the Pre-1992 Stored Gas Account is zero and AEC's Stored Gas Account is greater than zero, shall be deemed to be Sales Gas recovered or obtained by AEC on its own behalf, or

.3 the Pre-1992 Stored Gas Account and the Stored Gas Account of AEC are zero, shall be deemed to be Native Gas, or 
.2 by AEC on its own behalf while its Pre-1992 Stored Gas account and its Stored Gas Account zero, shall be deemed to be Native Gas.

4.5 AEC shall, in addition to the determinations called for in section 8.2 of the Agreement, make the following determinations for each Month following the end of that Month:

.1 the volume of Pre-1992 Sales Gas recovered or obtained in the Month,

.2 the volumes of Pre-1992 Stored Gas that the Pre-1992 Sales Gas is deemed under section 4.1 to be,

.3 the volume of Her Majesty royalty share of the Pre-1992 Sales Gas that is deemed under section 4.1 to have been Pre-1992 Stored Gas,

.4 the volume of Her Majesty's royalty share of any Pre-1992 Stored Gas that is deemed under section 8 of Schedule 1 of the Regulation to be volumes sold in that Month, and the previous Month in which AEC injected that Pre-1992 Stored Gas into the Leased Zone, and

.5 the volume of gas recovered, or obtained from natural gas recovered, from the Leased Zone during the Month that is deemed under section 4.4 to be Native Gas.

4.6 If the Minister disagrees with any determination made by AEC under section 4.5 the Minister may make the determination in accordance with sections 4.1, 4.2, 4.3 or 4.4 , as the case may be, and his determination shall prevail over any determination by AEC.

\subsection{Royalty}

5.1 Her Majesty's royalty share of any Pre-1992 Sales Gas recovered or obtained in a Month shall be sold, consumed or otherwise disposed of by AEC on Her Majesty's behalf along with the balance of that Pre-1992 Sales Gas, and AEC shall pay to Her Majesty in relation to that royalty share, at the time and in the manner specified in the Regulation, the excess of the product of the Energy Content of the royalty share and AEC's CAP for the Month, over the costs and allowances consented to by the Minister under the Regulation in respect of the royalty share.

5.2 AEC shall, in accordance with the Regulation, pay Her Majesty in relation to Her Majesty's royalty share of Pre-1992 Stored Gas that is deemed under section 8 of Schedule 1 of the Regulation to be volumes sold in a Month, the amount of money determined in accordance with the Regulation. 
5.3 Nothing in the Agreement shall derogate from the right of Her Majesty to prescribe royalty in respect of Pre-1992 Stored Gas and Pre-1992 Sales Gas that is deemed under section 4.1 to have been Pre-1992 Stored Gas.

5.4 Sections 17(1) and (2) of the Regulation shall not apply to Pre-1992 Stored Gas. 
Schedule 3 to the

Suffield Upper Mannville I

Crown Storage Agreement

Date of Issue:

THIS AGREEMENT made as of the Date of Issue

\section{BETWEEN:}

HER MAJESTY THE QUEEN in right of the Province of Alberta, hereinafter called "Her Majesty," as represented by the Minister of Energy, hereinafter called the "Minister"

\section{OF THE FIRST PART}

- and -

ALBERTA ENERGY COMPANY LTD., hereinafter called "AEC," a body corporate, incorporated under the laws of Alberta and having its head office at the City of Edmonton, in the Province of Alberta

\section{OF THE SECOND PART}

- and -

, hereinafter called the "Company"

\section{OF THE THIRD PART}

\section{WHEREAS:}

1.0 The Company has entered into a Company Agreement with AEC;

2.0 Her Majesty has approved the pro forma form of that contract and, along with AEC, is prepared to enter into a Subscription Agreement with the Company;

3.0 The Lieutenant Governor in Council by Order in Council dated September 23, 1992 and numbered O.C. 544/92 has authorized the Minister to enter into such a Subscription Agreement. 
NOW THEREFORE the parties hereto agree as follows:

\subsection{Name of Subscription Agreement}

1.1 This Agreement may be referred to as the " Subscription Agreement."

\subsection{Interpretation}

2.1 In this Agreement,

.1 "AEC Agreement" means the Suffield Upper Mannville I Crown Storage Agreement between Her Majesty an AEC, a copy of which is attached hereto as Schedule 1, as amended from time to time;

.2 "Term" means the period described in section 3.1.

2.2 Except as otherwise provided herein terms used in this Agreement have the same meaning as in the AEC Agreement.

2.3 The provisions of the AEC Agreement are incorporated herein and made a part hereof as though fully set out herein.

3.0 Term

3.1 The term of this Agreement commences 1,19 and, unless this Agreement is sooner cancelled pursuant to section 15.1, 15.3, 15.7 or 15.9 of the AEC Agreement, ends on the last day of the Term of the AEC Agreement.

\subsection{Company's Rights and Obligations}

4.1 The Company shall be a party to the AEC Agreement in accordance with the terms and conditions of the AEC Agreement and this Agreement.

4.2 The Company shall for the Term, above and be entitled to the rights and benefits conferred by the AEC Agreement on Storers other than AEC.

4.3 The Company shall, for the Term, have and accept the liabilities, abide by the terms and conditions, and accept and perform the obligations, imposed by the AEC Agreement on Storers other than AEC.

4.4 The Company acknowledges that pursuant to the AEC Agreement, the Minister may require AEC to provide a copy of the Company Agreement for review by the Minister.

4.5 This Agreement shall be binding upon an assignee of the rights and obligations of the Company under this Agreement and the AEC Agreement, so long as the assignment has been consented to by the Minister under the AEC Agreement. 


\subsection{Notices}

5.1 The address for service of all notices, consents, requests and other documents authorized or required to be given pursuant to this Agreement or the AEC Agreement shall, in the case of the Company, be as follows:

Fax:

IN WITNESS WHEREOF Her Majesty, AEC and the Company have executed this Agreement as of the Date of Issue.

HER MAJESTY THE QUEEN in right of the Province of Alberta, as represented by the Minister of Energy 